\title{
Analyses of conformational performance differentiation among functional breeding goals in the Menorca horse breed
}

\author{
Marina Solé', Maria Dolores Gómez ${ }^{1}$ Antonio Molina², Francisco Peña³ and Mercedes \\ Valera $^{1}$
}

'Departamento de Ciencias Agro-Forestales, ETSIA, Universidad de Sevilla, Sevilla, Spain, ${ }^{2}$ Departamento de Genetica, Facultad de Veterinaria, Universidad de Córdoba, Córdoba, Spain, ${ }^{3}$ Departamento de Producción Animal, Facultad de Veterinaria, Universidad de Córdoba, Córdoba, Spain

\section{Abstract}

The endangered Menorca horse from the Balearic Islands (Spain) is selected for its economically viable traits, such as conformation and dressage performance, while maintaining the maximum possible genetic variability. The aim of this work was to describe the morphology of the Menorca horse and to analyse the conformational variation among the different performance aptitudes of the males (classical dressage, Menorca dressage and leisure) using 47 body measurements and 10 body indices. The data consists of 147 females and 200 males. The Menorca horse can be characterised as an animal of quadrangular format, slim figure with thin and long limbs, with the greatest values for height and length found in the males. The Duncan and principal component analysis with non-linear iterative partial least-squares algorithm discriminates the Menorca dressage group mainly by its differential hind limb angulations. Both the classical and Menorca dressage groups showed well-balanced body proportions for sport performance.

Keywords: dressage, local breed, Menorca horse, morphology, sexual dimorphism

Abbreviations: PRMe: Menorca horse

Archiv Tierzucht 56 (2013) 37, 367-379

doi: $10.7482 / 0003-9438-56-038$

Corresponding author:

Marina Solé Berga; email: ge2sobem@uco.es

Departamento de Ciencias Agro-forestales, Escuela Técnica Superior de Ingeniería Agronómica, Universidad de Sevilla, Carretera de Utrera Km 1, 41013-Sevilla, Spain

() 2013 by the authors; licensee Leibniz Institute for Farm Animal Biology (FBN), Dummerstorf, Germany. This is an Open Access article distributed under the terms and conditions of the Creative Commons Attribution 3.0 License (http://creativecommons.org/licenses/by/3.0/).
Received: 4 October 2012

Accepted: 20 December 2012

Online: 22 March 2013 


\section{Introduction}

The Menorca horse breed (PRMe, Figure 1), traditionally known as "Caballo de Menorca", is an autochthonous equine breed of the Balearic Islands. The Stud-Book was opened in 1988 (Marqués 2001), but the origin of the breed is unclear and poorly studied, although the PRMe breed and the endangered Mallorca horse breed are related to the Spanish Celtic horse breeds (Cañon et al. 2000). The PRMe was recognized as an endangered horse breed by its small census (Azor et al. 2007). They are mainly located on the Menorca Island (Spain), but currently, they are also found in different autonomous regions of Spain and even in several countries of the European Union, such as France, Italy and the Netherlands. The PRMe is blackcoated and suitable for riding and is well-known for its role during the traditional festivities on the island of Menorca called "Jaleo Menorquín«. In these festivities, the horses have to move with easiness and carry out the traditional movements among crowds of people. The regularity of the movements is slightly modified by the speed.

The need to preserve genetic variability is essential and of maximum importance, given that it is the mainstay of genetic progress (De Rochambeau et al. 2000) and especially for this type of local breed with a small census. The breeding program of the PRMe has been developed by the Breeders' Association since 2007, in order to select breeding stock with the highest genetic potential for traits of economic interest, while maintaining as much genetic variability as possible by means of optimum selection procedures. The selection objectives involve both conformation and functional traits (ability to perform in classic dressage and Menorca dressage, a special type of dressage that includes the typical Menorcan movements the animals perform at the traditional festivities).

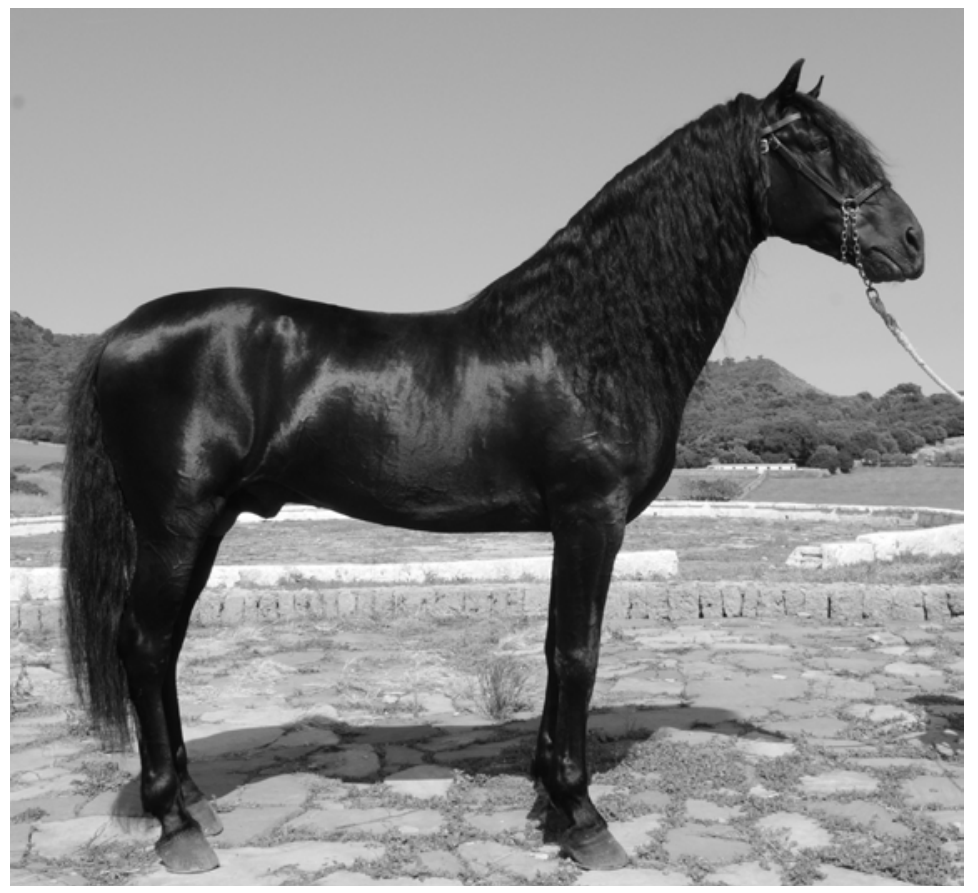

Figure 1

"Puderos" - typical Menorca horse, breed champion in 2010 
The evaluation of conformation traits is essential to ensure quality and to improve racial characteristics of the equine livestock in a continuous and systematic way (García et al. 2000). Moreover, in horse breeding, conformation is an important factor, since the morphology of the body defines the horses' gait, movements, locomotion and, ultimately, their sports performance (Langlois et al. 1978, 1979, Holmström et al. 1990, Mawdsley et al. 1996). Therefore, insufficient knowledge of the influence of conformation on performance and on the horses' own health and welfare may lead to unsuitable selection of candidates for breeding (Holmström \& Philipsson 1993).

Breed characterisation is the initial approach to a sustainable use of animal genetic resources (Lanari et al. 2003). In this regard, zoometric measurements provide us objective information on the conformation of the animals, referring to the different body regions, on which we can base a study of the racial characteristics of the population. The analysis of morphological traits is currently carried out as on-going research in the fields of horse breeding and genetics (Komosa \& Purzyc 2009).

The aim of this study was to record the most important body measurements and morphological indices of the PRMe to determine the differences between sexes and to study the influence of the type of sports activity on the morphology of the stallions selected for different performance aptitudes.

\section{Material and methods}

\section{Sampling}

A total of 347 individuals (200 stallions and 147 breeding mares), ranging between 4 and 14 years old, were sampled for conformation analyses on the island of Menorca (Spain) during 2009 and 2010, following the methodology described by Gómez et al. (2009) and Cervantes et al. (2009).

Up until now, females of this breed have featured very little in dressage performances, as they are preferentially used for breeding and thus, only males were classified for three different performance aptitudes (classical dressage, Menorca dressage, leisure; Table 1).

Table 1

Number of males sampled for each performance aptitude, number of females and distribution over age range of the Menorca horses analysed

\begin{tabular}{llccc}
\hline Sex & Aptitude & 3-6 years old & $\begin{array}{c}\text { Individuals sampled } \\
\geq 7 \text { years old }\end{array}$ & total \\
\hline Males & classical dressage & 37 & 59 & 96 \\
& Menorca dressage & 25 & 49 & 74 \\
& leisure & 17 & 13 & 30 \\
Females & leisure & 36 & 111 & 147 \\
\hline
\end{tabular}

Forty seven body measurements (Figure 2) were recorded using a zoometric stick and a nonelastic tape taken by the same trained qualifier from the left side on a hard, level floor. The angles were obtained using the ImageJ software (Abràmoff et al. 2004). For this purpose white marks were made on specific anatomical reference points on the horse. 
The following measurements were used:

- 33 distance measurements: head length (HeL), head width (HeW), skull length (SkL), skull width (SkW), face length (FaL), face width (FaW), ear length (EL), chest width (CW), neck length (NL), scapula length (SL), arm length ( $A L)$, forearm length (FarL), fore-cannon length (CaL), dorso-esternal diameter (DED), bicostal diameter (BD), body length (BL), back length (BaL), loin length (LoL), hip-stifle length (HSL), buttock-stifle length (BSL), croup length $(\mathrm{CL})$, croup width $(\mathrm{CW})$, buttock length (BuL), leg length (LL), height at withers $(\mathrm{HW})$, height after withers (HaW), height of withers (HoW), middle back height $(\mathrm{MbH})$, fore croup height $(\mathrm{CH})$, height at hip $(\mathrm{HH})$, equilibrium withers-hip $(\mathrm{EWH})$, hind croup height $(\mathrm{HCH})$, height at tail $(\mathrm{HT})$,

- 6 perimeters: central neck perimeter (NP), fore knee perimeter (KP), fore-cannon perimeter $(C P)$, fore fetlock perimeter (FP), fore hoof perimeter (HP), thoracic perimeter (TP),

- 8 angular measurements: neck angle $(\eta)$, scapula angle $(\alpha)$, arm angle $(\beta)$, croup angle $(\varphi)$, stifle angle $(\varepsilon)$, femur angle $(\omega)$, leg angle $(\theta)$ and hock angle $(\delta)$.

Using these body measurements, a total of 10 body indices were estimated in order to define the general conformation of these animals as described in Gómez et al. (2012):

- body index (BI): BLX100/TP, proportionality index (Prl): HW/BL, thoracic index (TI): $B D \times 100 / D E D$, dactyl-thoracic index (DTI): CP×100/TP, dactyl-costal index (DCl): CP×100/ $\mathrm{CW}$, relative thickness of the cane bone index $(\mathrm{RTCl}): \mathrm{CP} \times 100 / \mathrm{HW}$, pelvic index $(\mathrm{PI})$ : $\mathrm{CW} \times 100 / \mathrm{CL}$, longitudinal pelvic index $(\mathrm{LPI})$ : $\mathrm{CL} \times 100 / \mathrm{HW}$, transversal pelvic index (TPI): $\mathrm{CW} \times 100 / \mathrm{HW}$, relative proportionality of the thorax index (RPTI): DED/HW.

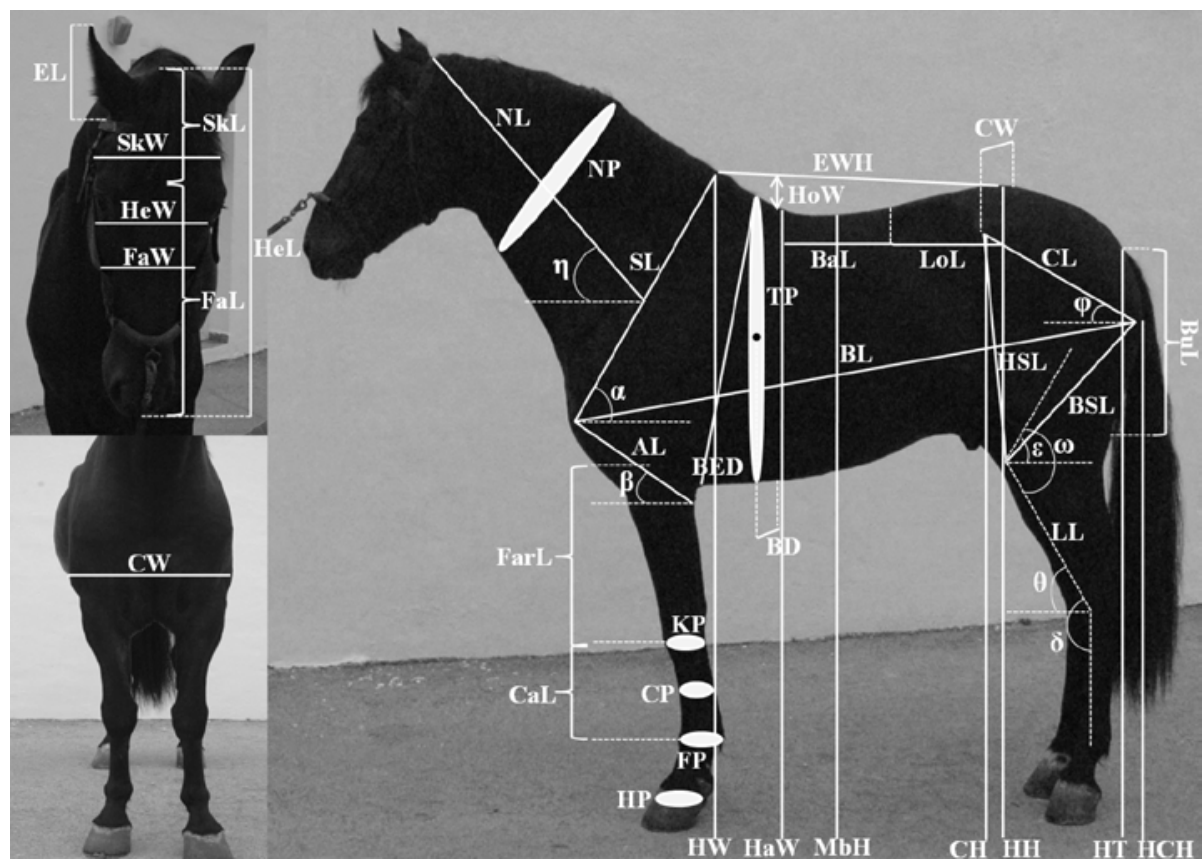

Figure 2

Body measurements studied in the Menorca Horse population 


\section{Statistical analyses}

All the statistical analyses for the body measurements and indices were carried out using different procedures of the Statistics for Windows v.8.0 package (StatSoft, Inc, Tulsa, OK, USA). Descriptive statistics of the body measurements were estimated separately for males and females. The mean significance of differences between sexes was evaluated by a pairwise T-test. A Duncan's multiple-range test was computed to mean difference performance aptitude groups within males. Additionally, we used the classical statistical analysis based on morphological traits (zoometric measurements), but including principal component analysis (PCA) with a non-linear iterative partial least-squares (NIPALS) algorithm to detect correlations between conformational traits and performance aptitudes. This is a sequential method through which, in every cycle, a principal component is calculated directly from the data matrix (Geladi \& Kowalski 1986), enabling us to obtain the maximum information out of a smaller number of components than conventional methods of principal components. It also has the advantage of being less affected by strong collinearity between variables.

\section{Results and discussion}

The statistical significance of the pairwise t-test analyses between sexes among the 47 body measurements and the 10 body indices are given in Table 2 (measurements) and Table 3 (body indices). Sexual dimorphism can be phenotypically expressed as differences in skeletal size and/or body mass (Okpeku et al. 2011). Here, the pairwise t-test reveals significant differences for $80 \%$ of the traits under study, indicating the existence of a strong sexual dimorphism in PRMe. The greatest values for heights and lengths were found for males and females showed thinner necks than males. Only some lengths and angulations, mainly of the hind limbs, showed no significant differences between sexes. The morphological measurements related to the head and face are useful discriminant variables to classify the two sexes in other species (Yakubu et al. 2010) and in the case of the PRMe, these variables (i.e. head length and width or face width, Table 2) were also discriminative between males and females, allowing us to clearly distinguish between the two sexes.

A relative comparison of PRMe population with other horse breeds indicates that they generally have a height at the wither greater than other horse breeds of a similar body weight, such as the Mangalarga Marchador horse $(148.31 \mathrm{~cm}$; Pinto et al. 2008) or the Lipizzan horse (155.11 cm; Zechner et al. 2001) and slightly higher than the Spanish Purebred horse (155-158cm, Molina et al. 1999, Gómez et al. 2009) and Friesian horses (158.8; Pretorius et al. 2004), but very similar to Czech cold-blooded horses (159.88; Vostrý et al. 2011). Moreover, the body length of the Spanish Purebred was $159 \mathrm{~cm}$ (Gómez et al. 2009) and for the Lipizzan horses it was $160.5 \mathrm{~cm}$ (Zechner et al. 2001), which are both very similar to the PRMe (159 cm, Table 2). The height at withers and thebody length ratio categorise the PRMe as a breed of quadrangular format. In a horse with good balance (Lawrence 2006) the croup should be approximately the same height as the withers, a characteristic which can be observed in PRMe breed. 
Table 2

Means pairwise t-test analysis for 47 body measurements between sexes, taken from the 347 Menorca horses analysed

\begin{tabular}{|c|c|c|c|c|}
\hline Body measurements & males & $\begin{array}{c}\text { Mean } \pm S D \\
\text { females }\end{array}$ & t-value & $P$ \\
\hline Head length & $0.61 \pm 0.02$ & $0.60 \pm 0.02$ & 2.23 & ** \\
\hline Head width & $0.23 \pm 0.01$ & $0.22 \pm 0.01$ & 4.80 & ** \\
\hline Skull length & $0.21 \pm 0.02$ & $0.20 \pm 0.02$ & 2.73 & ** \\
\hline Skull width & $0.16 \pm 0.02$ & $0.15 \pm 0.02$ & 2.36 & ** \\
\hline Face length & $0.40 \pm 0.02$ & $0.40 \pm 0.02$ & -0.36 & ns \\
\hline Face width & $0.18 \pm 0.01$ & $0.17 \pm 0.01$ & 3.86 & ** \\
\hline Ear length & $0.16 \pm 0.01$ & $0.17 \pm 0.01$ & -5.00 & ** \\
\hline Chest width & $0.43 \pm 0.03$ & $0.39 \pm 0.03$ & 8.93 & ** \\
\hline Neck length & $0.72 \pm 0.04$ & $0.70 \pm 0.04$ & 4.67 & $* *$ \\
\hline Scapula length & $0.64 \pm 0.02$ & $0.61 \pm 0.03$ & 8.36 & ** \\
\hline Arm length & $0.38 \pm 0.02$ & $0.37 \pm 0.02$ & 6.94 & ** \\
\hline Forearm length & $0.43 \pm 0.02$ & $0.44 \pm 0.02$ & -1.89 & ns \\
\hline Fore-cannon length & $0.28 \pm 0.01$ & $0.27 \pm 0.01$ & 5.64 & ** \\
\hline Back-sternal diameter & $0.66 \pm 0.02$ & $0.67 \pm 0.03$ & -3.77 & $* *$ \\
\hline Bicostal diameter & $0.49 \pm 0.04$ & $0.50 \pm 0.05$ & -1.54 & ns \\
\hline Body length & $1.59 \pm 0.06$ & $1.59 \pm 0.04$ & -0.98 & ns \\
\hline Back length & $0.31 \pm 0.02$ & $0.31 \pm 0.02$ & -1.63 & ns \\
\hline Loin length & $0.32 \pm 0.02$ & $0.33 \pm 0.03$ & -3.56 & $* *$ \\
\hline Hip-stifle length & $0.47 \pm 0.03$ & $0.47 \pm 0.03$ & -1.41 & ns \\
\hline Buttock-stifle length & $0.52 \pm 0.02$ & $0.50 \pm 0.02$ & 4.16 & ** \\
\hline Croup length & $0.53 \pm 0.03$ & $0.50 \pm 0.02$ & 3.78 & ** \\
\hline Croup width & $0.51 \pm 0.02$ & $0.52 \pm 0.02$ & -4.69 & ** \\
\hline Buttock length & $0.44 \pm 0.02$ & $0.43 \pm 0.02$ & 4.75 & ** \\
\hline Leg length & $0.55 \pm 0.02$ & $0.53 \pm 0.03$ & 6.12 & $* *$ \\
\hline Height at withers & $1.62 \pm 0.04$ & $1.57 \pm 0.04$ & 9.87 & ** \\
\hline Height after withers & $1.53 \pm 0.04$ & $1.49 \pm 0.04$ & 6.77 & ** \\
\hline Height of withers & $0.09 \pm 0.02$ & $0.08 \pm 0.01$ & 6.13 & ** \\
\hline Middle back height & $1.51 \pm 0.04$ & $1.48 \pm 0.04$ & 6.19 & ** \\
\hline Fore croup height & $1.48 \pm 0.04$ & $1.45 \pm 0.04$ & 6.17 & ** \\
\hline Height at hip & $1.59 \pm 0.04$ & $1.56 \pm 0.04$ & 6.61 & $* *$ \\
\hline Withers-hip Equilibrium & $0.02 \pm 0.02$ & $0.01 \pm 0.02$ & 5.79 & ** \\
\hline Hind croup height & $1.59 \pm 0.04$ & $1.56 \pm 0.04$ & 6.61 & ** \\
\hline Height at tail & $1.48 \pm 0.04$ & $1.44 \pm 0.04$ & 7.35 & $* *$ \\
\hline Central neck perimeter & $1.11 \pm 0.07$ & $0.97 \pm 0.05$ & 19.28 & $* *$ \\
\hline Fore knee perimeter & $0.34 \pm 0.01$ & $0.31 \pm 0.01$ & 19.31 & ** \\
\hline Fore-cannon perimeter & $0.21 \pm 0.01$ & $0.19 \pm 0.00$ & 11.93 & $* *$ \\
\hline Fore fetlock perimeter & $0.28 \pm 0.01$ & $0.27 \pm 0.01$ & 8.52 & ** \\
\hline Fore hoof perimeter & $0.37 \pm 0.01$ & $0.38 \pm 0.01$ & -3.06 & ** \\
\hline Thoracic perimeter & $1.83 \pm 0.06$ & $1.86 \pm 0.08$ & -3.98 & ** \\
\hline Neck angle & $34.09 \pm 9.98$ & $34.13 \pm 10.06$ & -0.04 & ns \\
\hline Scapula angle & $55.28 \pm 4.16$ & $58.53 \pm 4.46$ & -6.95 & ** \\
\hline Arm angle & $31.02 \pm 5.93$ & $29.46 \pm 7.00$ & 2.25 & ** \\
\hline Croup angle & $15.76 \pm 4.93$ & $18.51 \pm 4.89$ & -5.15 & ** \\
\hline Stifle angle & $123.18 \pm 8.28$ & $125.38 \pm 8.23$ & -2.44 & $* *$ \\
\hline Femur angle & $65.37 \pm 5.77$ & $64.96 \pm 5.83$ & 0.64 & ns \\
\hline Leg angle & $58.70 \pm 5.52$ & $60.52 \pm 6.72$ & -2.76 & $* *$ \\
\hline Hock angle & $137.33 \pm 7.41$ & $136.94 \pm 5.46$ & 0.54 & ns \\
\hline
\end{tabular}

Measurements in $\mathrm{m}$, angles in degrees; ns: not significant, ${ }^{* *}$ statistical significance differences within groups at $P<0.01$ 
The neck is classified as long (neck length $=72 \mathrm{~cm}$ ) since it is over one third of the body length. The neck also tends to the horizon (neck angle $=34^{\circ}$, Table 2). These characteristics, in both length and angle of the neck, are advantageous for every sport. The PRMe breed has a shoulder of good length $(60-63 \mathrm{~cm})$, enabling an extension of stride that is needed in dressage. The arm is long, over $60 \%$ of the length of the shoulder, but the angle to the shoulder is small, below $100-120^{\circ}$. A sloping shoulder leads to the decreasing of the angle between the scapula and humerus, which reduces the risk of concussion (Lawrence 2006). Likewise, the overall mean of the PRMe for forearm length was $44 \mathrm{~cm}$ and for fore-cannon length it was $28 \mathrm{~cm}$ (Table 2), which is similar to that of the Mangalarga Marchador horse (45.17 for forearm length and 27.99 for fore-cannon length; Pinto et al. 2008). However, the means obtained for the forelimb lengths were higher than those of the Lipizzan horse described above, ranging between 38.6 to $40.4 \mathrm{~cm}$ for the fore-arm length and between 23.2 and $25.6 \mathrm{~cm}$ for the fore-cannon length (Zechner et al. 2001). A long fore-arm is desirable, especially if the horse also has a short cannon, since it increases the leverage for maximum stride length and speed (Lawrence 2006). The fore-arm length / fore-cannon length ratio (1.6) was similar to that recorded in the breeds described above, while the fore-cannon perimeter obtained $(0.20 \mathrm{~cm}$, Table 2) was lower than that of Czech cold-blooded and Friesian horses $(0.23 \mathrm{~cm}$ both; Pretorius et al. 2004; Vostrý et al. 2011), perhaps because of the different uses of these breeds. The results suggest that the PRMe could be classified and identified as an animal with long, thin limbs, which are particularly characteristic of the PRMe population. The length and slope of the croup have a strong correlation to a horse's function: here, the croup is square or slightly pear-shaped and relatively flat. These features allow the topline to continue in a relatively flat manner to the dock of the tail and encourage a long stride.

As regards angulations, the PRMe obtained lower values than, for example, the Mangalarga Marchador horse. The scapula and croup inclinations are important measurements for several sport performance horse breeds. Holmström et al. (1990) observed mean values for the scapula inclination of $65.3^{\circ}$ and for the Croup of $29.9^{\circ}$ in Swedish Warmblood dressage horses. The lower values obtained for the PRMe (Table 2) suggest that this breed has not suffered the intense pressure of selection for dressage performance. These traits are susceptible candidates to be included in the breeding program of the breed.

Table 3

Means pairwise t-test analysis for 10 body indices between sexes taken from the 347 Menorca horses analysed

\begin{tabular}{lcccr}
\hline Body indices & males & $\begin{array}{c}\text { Mean } \pm \text { SD } \\
\text { females }\end{array}$ & t-value & $P$ \\
\hline Body index & $87.00 \pm 3.49$ & $85.92 \pm 3.09$ & 2.99 & $* *$ \\
Proportionality index & $101.86 \pm 2.97$ & $98.43 \pm 2.67$ & 11.10 & $* *$ \\
Thoracic index & $75.89 \pm 6.46$ & $75.83 \pm 10.46$ & 0.06 & $\mathrm{~ns}$ \\
Dactyl-thoracic index & $11.31 \pm 0.55$ & $10.50 \pm 0.62$ & 12.63 & $* *$ \\
Dactyl-costal index & $41.92 \pm 3.53$ & $39.10 \pm 4.51$ & 6.50 & $* *$ \\
Relative thickness of the cane bone index & $12.77 \pm 0.52$ & $12.43 \pm 0.67$ & 5.37 & $* *$ \\
Pelvic index & $0.96 \pm 0.05$ & $1.01 \pm 0.06$ & -7.71 & $* *$ \\
Longitudinal pelvic index & $32.45 \pm 1.71$ & $32.67 \pm 1.58$ & -1.22 & $\mathrm{~ns}$ \\
Transversal pelvic index & $31.27 \pm 1.41$ & $33.08 \pm 1.57$ & -11.18 & $* *$ \\
Relative proportionality of thorax index & $40.44 \pm 1.45$ & $42.52 \pm 2.10$ & -10.87 & $* *$ \\
\hline
\end{tabular}

ns: not significant, ${ }^{* *}$ statistical significance differences within groups at $P<0.01$ 
The PRMe also showed a clear differentiation in body indices (Table 3) with draft horses or those used for meat production, such as the heavy horse populations studied by Gómez et al. (2012). The body index or proportionality index are useful parameters and are important in assessing functionality (Takaendengan et al. 2011). Here, the PRMe showed a greater body size (85 to 87 , Table 3 ) than horses used for sport performance. They also showed suitable body structure as a saddle horse, since they are lighter than the heavy horse populations used for meat production (Gómez et al. 2012).

Bone development is shown by the dactyl-thoracic, dactyl-costal and relative thickness of the cannon bone indices. The values obtained for males and females showed that the PRMe had a lower bone development being useful for sport performance due to its lightness. Therefore, the PRMe can be characterised by its slim figure, with long, thin limbs. Long limbs are of special importance, as the length of the limbs affects not only the height or the appearance of an animal but also the quality of its gaits and practical predispositions (Komosa \& Purzyc 2009). In the same way, croup conformation is shown by both the longitudinal pelvic and transversal pelvic indices. These indices show that the PRMe population had correct values, with females squarer in shape than males (pelvic index of 1.01, Table 3). Moreover, they obtained lower longitudinal pelvic and transversal pelvic indices than heavy horse populations (Gómez et al. 2012), which could be caused by the breeders' indirect selection to obtain the finest saddle horses. The thorax depth relative to the height at withers was evidenced by the relative proportionality of the thorax index (the higher values are linked to greater depth), with females better than males in this index.

The main studies carried out on horses have shown that conformation and dressage ability are related (Barrey et al. 2002). Body dimensions and certain conformation traits have been reported to be desirable and advantageous for performance in particular disciplines, such as dressage (Holmström et al. 1990). Here, Table 4 shows mean values, standard deviations and the statistical significance of the Duncan test analyses between the performance aptitudes groups (classical dressage, Menorca dressage, leisure) among the PRMe stallions analysed for the 47 body measurements and those for the 10 body indices are given in Table 5 .

The Duncan test reveals significant differences between males classified into the three different performance aptitudes groups for $24.5 \%$ of the traits under study. Males belonging to the classical dressage group showed fewer differences with the other two groups: only chest width $(0.43 \mathrm{~cm})$ and height at tail $(1.48 \mathrm{~cm})$ were greater in this group. Barrey et al. (2002) observed conformation differences between dressage breeds (German, French and Spanish horses) mainly related with limb lengths and joint angles. In the present work, differences between performance aptitude groups within the same breed have also been confirmed.

The values for traits related to withers and croup conformational variables were lower in the Menorca Dressage group (for example, height at withers was $1.61 \mathrm{~cm}$ and croup angle was $15.21^{\circ}$ : see Table 4), while hind limb angles were greater $\left(125.27^{\circ}\right.$ for stifle and $66.01^{\circ}$ for femur angles), highlighting the importance of hind limb conformation to perform some movements included in Menorca dressage (e.g. »el bot«). Otherwise, for most of the traits with significant differences, the leisure group showed the highest average values for the lengths of head $(0.62 \mathrm{~cm})$, face $(0.41 \mathrm{~cm})$ and hip-stifle $(0.48 \mathrm{~cm})$. Some of the traits analysed were significantly similar between leisure and classical dressage groups (e.g. back-sternal diameter, croup width, fetlock perimeter or croup angle, amongst others). The differences 
Table 4

Duncan test to means comparison for 47 body measurements between aptitudes taken from the 200 males of the Menorca horses analysed

\begin{tabular}{|c|c|c|c|c|c|c|}
\hline \multirow[t]{3}{*}{ Body measurements } & \multicolumn{6}{|c|}{ Aptitude } \\
\hline & \multicolumn{2}{|c|}{ classical dressage } & \multicolumn{2}{|c|}{ Menorca dressage } & \multicolumn{2}{|c|}{ leisure } \\
\hline & Mean & SD & Mean & SD & Mean & SD \\
\hline Head length & $0.61^{\mathrm{a}}$ & 0.03 & $0.61^{\mathrm{a}}$ & 0.02 & $0.62^{\mathrm{b}}$ & 0.03 \\
\hline Head width & $0.23^{\mathrm{a}}$ & 0.01 & $0.23^{\mathrm{a}}$ & 0.01 & $0.23^{\mathrm{a}}$ & 0.01 \\
\hline Skull length & $0.20^{\mathrm{a}}$ & 0.02 & $0.21^{\mathrm{a}}$ & 0.02 & $0.21^{\mathrm{a}}$ & 0.03 \\
\hline Skull width & $0.16^{a}$ & 0.02 & $0.16^{\mathrm{a}}$ & 0.02 & $0.17^{\mathrm{a}}$ & 0.02 \\
\hline Face length & $0.41^{\mathrm{ab}}$ & 0.02 & $0.39^{\mathrm{a}}$ & 0.02 & $0.41^{b}$ & 0.03 \\
\hline Face width & $0.18^{\mathrm{a}}$ & 0.02 & $0.18^{\mathrm{a}}$ & 0.01 & $0.19^{\mathrm{a}}$ & 0.02 \\
\hline Ear length & $0.16^{\mathrm{a}}$ & 0.01 & $0.16^{\mathrm{a}}$ & 0.02 & $0.16^{\mathrm{a}}$ & 0.01 \\
\hline Chest width & $0.43^{b}$ & 0.03 & $0.43^{\mathrm{ab}}$ & 0.03 & $0.42^{\mathrm{a}}$ & 0.04 \\
\hline Neck length & $0.73^{\mathrm{a}}$ & 0.04 & $0.72^{\mathrm{a}}$ & 0.05 & $0.73^{\mathrm{a}}$ & 0.05 \\
\hline Scapula length & $0.64^{\mathrm{a}}$ & 0.03 & $0.63^{\mathrm{a}}$ & 0.03 & $0.63^{\mathrm{a}}$ & 0.03 \\
\hline Arm length & $0.38^{\mathrm{a}}$ & 0.02 & $0.38^{\mathrm{a}}$ & 0.02 & $0.38^{\mathrm{a}}$ & 0.02 \\
\hline Forearm length & $0.44^{\mathrm{a}}$ & 0.03 & $0.44^{\mathrm{a}}$ & 0.03 & $0.43^{\mathrm{a}}$ & 0.03 \\
\hline Fore-cannon length & $0.28^{\mathrm{a}}$ & 0.02 & $0.28^{\mathrm{a}}$ & 0.02 & $0.28^{\mathrm{a}}$ & 0.02 \\
\hline Back-sternal diameter & $0.66^{\mathrm{ab}}$ & 0.03 & $0.65^{\mathrm{a}}$ & 0.03 & $0.66^{\mathrm{b}}$ & 0.03 \\
\hline Bicostal diameter & $0.50^{\mathrm{a}}$ & 0.04 & $0.49^{\mathrm{a}}$ & 0.04 & $0.50^{\mathrm{a}}$ & 0.06 \\
\hline Body length & $1.60^{\mathrm{a}}$ & 0.06 & $1.59^{\mathrm{a}}$ & 0.06 & $1.58^{\mathrm{a}}$ & 0.06 \\
\hline Back length & $0.31^{\mathrm{a}}$ & 0.02 & $0.31^{\mathrm{a}}$ & 0.02 & $0.31^{\mathrm{a}}$ & 0.03 \\
\hline Loin length & $0.31^{\mathrm{a}}$ & 0.03 & $0.31^{\mathrm{a}}$ & 0.03 & $0.32^{\mathrm{a}}$ & 0.03 \\
\hline Hip-stifle length & $0.47^{\mathrm{A}}$ & 0.04 & $0.47^{\mathrm{A}}$ & 0.03 & $0.48^{\mathrm{B}}$ & 0.04 \\
\hline Buttock-stifle length & $0.52^{\mathrm{a}}$ & 0.03 & $0.51^{\mathrm{a}}$ & 0.02 & $0.51^{\mathrm{a}}$ & 0.03 \\
\hline Croup length & $0.53^{\mathrm{a}}$ & 0.03 & $0.52^{\mathrm{a}}$ & 0.03 & $0.53^{\mathrm{a}}$ & 0.03 \\
\hline Croup width & $0.51^{\mathrm{AB}}$ & 0.02 & $0.50^{\mathrm{A}}$ & 0.02 & $0.51^{\mathrm{B}}$ & 0.03 \\
\hline Buttock length & $0.44^{\mathrm{a}}$ & 0.03 & $0.44^{\mathrm{a}}$ & 0.02 & $0.44^{\mathrm{a}}$ & 0.03 \\
\hline Leg length & $0.55^{\mathrm{a}}$ & 0.03 & $0.55^{\mathrm{a}}$ & 0.03 & $0.56^{\mathrm{a}}$ & 0.03 \\
\hline Height at withers & $1.63^{b}$ & 0.05 & $1.61^{\mathrm{a}}$ & 0.05 & $1.62^{\mathrm{b}}$ & 0.05 \\
\hline Height after withers & $1.53^{\mathrm{a}}$ & 0.05 & $1.52^{\mathrm{a}}$ & 0.04 & $1.53^{\mathrm{a}}$ & 0.05 \\
\hline Height of withers & $0.09^{\mathrm{a}}$ & 0.02 & $0.09^{\mathrm{a}}$ & 0.02 & $0.10^{\mathrm{a}}$ & 0.02 \\
\hline Middle back height & $1.52^{\mathrm{a}}$ & 0.05 & $1.51^{\mathrm{a}}$ & 0.04 & $1.51^{\mathrm{a}}$ & 0.05 \\
\hline Fore croup height & $1.49^{\mathrm{a}}$ & 0.04 & $1.47^{\mathrm{a}}$ & 0.04 & $1.48^{\mathrm{a}}$ & 0.04 \\
\hline Height at hip & $1.60^{\mathrm{a}}$ & 0.05 & $1.59^{\mathrm{a}}$ & 0.04 & $1.59^{\mathrm{a}}$ & 0.05 \\
\hline Withers-hip equilibrium & $0.03^{A B}$ & 0.03 & $0.02^{\mathrm{A}}$ & 0.02 & $0.04^{\mathrm{B}}$ & 0.03 \\
\hline Hind croup height & $1.37^{\mathrm{a}}$ & 0.05 & $1.37^{\mathrm{a}}$ & 0.06 & $1.36^{\mathrm{a}}$ & 0.05 \\
\hline Height at tail & $1.48^{\mathrm{b}}$ & 0.04 & $1.47^{\mathrm{ab}}$ & 0.04 & $1.46^{\mathrm{a}}$ & 0.04 \\
\hline Central neck perimeter & $1.11^{\mathrm{a}}$ & 0.07 & $1.12^{\mathrm{a}}$ & 0.08 & $1.10^{\mathrm{a}}$ & 0.07 \\
\hline Fore knee perimeter & $0.34^{\mathrm{a}}$ & 0.02 & $0.34^{\mathrm{a}}$ & 0.01 & $0.34^{\mathrm{a}}$ & 0.02 \\
\hline Fore-cannon perimeter & $0.21^{\mathrm{ab}}$ & 0.01 & $0.21^{\mathrm{a}}$ & 0.01 & $0.21^{b}$ & 0.01 \\
\hline Fore fetlock perimeter & $0.29^{a}$ & 0.02 & $0.28^{\mathrm{a}}$ & 0.02 & $0.28^{\mathrm{a}}$ & 0.02 \\
\hline Fore hoof perimeter & $0.38^{\mathrm{a}}$ & 0.02 & $0.37^{\mathrm{a}}$ & 0.02 & $0.38^{\mathrm{a}}$ & 0.02 \\
\hline Thoracic perimeter & $1.83^{\mathrm{a}}$ & 0.06 & $1.82^{\mathrm{a}}$ & 0.06 & $1.84^{\mathrm{a}}$ & 0.07 \\
\hline Neck angle & $34.12^{\mathrm{a}}$ & 9.97 & $34.58^{\mathrm{a}}$ & 9.36 & $32.83^{\mathrm{a}}$ & 11.63 \\
\hline Scapula angle & $55.33^{\mathrm{a}}$ & 4.36 & $54.90^{\mathrm{a}}$ & 4.10 & $56.08^{\mathrm{a}}$ & 3.69 \\
\hline Arm angle & $31.03^{\mathrm{a}}$ & 5.37 & $31.11^{\mathrm{a}}$ & 6.88 & $30.83^{\mathrm{a}}$ & 5.26 \\
\hline Croup angle & $15.70^{A B}$ & 4.80 & $15.21^{\mathrm{A}}$ & 4.92 & $17.30^{\mathrm{B}}$ & 5.24 \\
\hline Stifle angle & $121.97^{\mathrm{ab}}$ & 9.44 & $125.27^{b}$ & 7.05 & $121.84^{\mathrm{a}}$ & 6.10 \\
\hline Femur angle & $65.27^{\mathrm{ab}}$ & 5.97 & $66.01^{b}$ & 5.65 & $64.12^{\mathrm{a}}$ & 5.39 \\
\hline Leg angle & $58.21^{\mathrm{a}}$ & 5.88 & $59.66^{a}$ & 5.47 & $57.89^{a}$ & 4.17 \\
\hline Hock angle & $137.01^{\mathrm{a}}$ & 7.58 & $138.20^{\mathrm{a}}$ & 6.99 & $136.23^{\mathrm{a}}$ & 7.95 \\
\hline
\end{tabular}

measurements in $\mathrm{m}$, angles in degrees, a,b,cifferent letters in the same row mean significant differences at $P<0.05$, $A, B, C$ Different letters in the same row mean significant differences at $P<0.01$ (Duncan test). 
observed within the three performance aptitudes groups studied suggest that horses with (or without) a specific dressage aptitude can be differentiated by morphological type. The main differences were observed in hind limb conformation (length, width and angles). Similar results were reported by Cervantes et al. (2009) using geometric morphometric methods, where the Spanish Arab horse population analysed showed differences in the functional posterior triangle.

Table 5

Means for 10 body indices, standard deviations and Duncan analysis for body measurements taken from 200 males of the Menorca horses analysed

\begin{tabular}{lcccccc}
\hline Body indices & \multicolumn{3}{c}{ Aptitude } & \\
& classical dressage & \multicolumn{2}{c}{ Menorca dressage } & leisure \\
& Mean & SD & Mean & SD & Mean & SD \\
\hline Body index & $87.25^{\mathrm{a}}$ & 3.53 & $87.10^{\mathrm{a}}$ & 3.49 & $85.99^{\mathrm{a}}$ & 3.32 \\
Proportionality index & $101.92^{\mathrm{ab}}$ & 3.08 & $101.37^{\mathrm{a}}$ & 2.65 & $102.89^{\mathrm{b}}$ & 3.21 \\
Thoracic index & $75.52^{\mathrm{a}}$ & 5.55 & $76.34^{\mathrm{a}}$ & 7.14 & $75.97^{\mathrm{a}}$ & 7.55 \\
Dactyl-thoracic index & $11.34^{\mathrm{a}}$ & 0.59 & $11.27^{\mathrm{a}}$ & 0.52 & $11.34^{\mathrm{a}}$ & 0.57 \\
Dactyl-costal index & $41.98^{\mathrm{a}}$ & 3.16 & $41.85^{\mathrm{a}}$ & 3.76 & $41.93^{\mathrm{a}}$ & 4.17 \\
Relative thickness of the cane bone index & $12.77^{\mathrm{a}}$ & 0.55 & $12.78^{\mathrm{a}}$ & 0.51 & $12.82^{\mathrm{a}}$ & 0.47 \\
Pelvic index & $0.96^{\mathrm{a}}$ & 0.05 & $0.97^{\mathrm{a}}$ & 0.06 & $0.98^{\mathrm{a}}$ & 0.06 \\
Longitudinal pelvic index & $32.61^{\mathrm{a}}$ & 1.66 & $32.31^{\mathrm{a}}$ & 1.83 & $32.34^{\mathrm{a}}$ & 1.57 \\
Transversal pelvic index & $31.16^{\mathrm{a}}$ & 1.40 & $31.28^{\mathrm{a}}$ & 1.47 & $31.64^{\mathrm{a}}$ & 1.30 \\
Relative proportionality of thorax index & $40.47^{\mathrm{a}}$ & 1.24 & $40.34^{\mathrm{a}}$ & 1.81 & $40.63^{\mathrm{a}}$ & 1.15 \\
\hline
\end{tabular}

$a, b, c$ Different letters in the same row mean significant differences at $P<0.05$ (Duncan test).

The appearance of symmetry and balance may be an important factor for a dressage horse. Among all the indices, that of relative proportionality was the only one showing significant differences between groups. The proportionality index is a measure of the proportionality of the body (values around 100 are linked to good proportion - height at withers and body length similar- and a better conformation for dressage performance). As expected, the Classical and Menorca Dressage groups showed the best values in this index (Table 5), which suggests that conformation proportionality plays an important role in dressage performance. A horse with a good conformation is more likely to have naturally good balanced body proportions than one with major conformation faults (Duberstein 2012).

The selection of horses according to functional criteria and the breeding of horses with body types most suitable for those particular functions are common practices of breed registries and breeders (Brooks et al. 2010). Accordingly, Figure 3 gives a graphical representation of the principal component analysis using a non-linear iterative partial leastsquares algorithm for the morphological variables and the three different performance aptitudes groups studied. The correlations between the main factors and the analysed variables can be observed (see table included in Figure 3). The first factor accounted for $25.3 \%$ of total variance and included most of the height and length variables that make up the general size of the horse. The second factor accounted for $8.5 \%$ and included most of the angular variables representing the functional root. The most closely correlated traits with the three performance aptitudes groups studied (classical dressage, Menorca dressage, leisure) were mainly angulations and withers variables. The classical dressage group was closely 


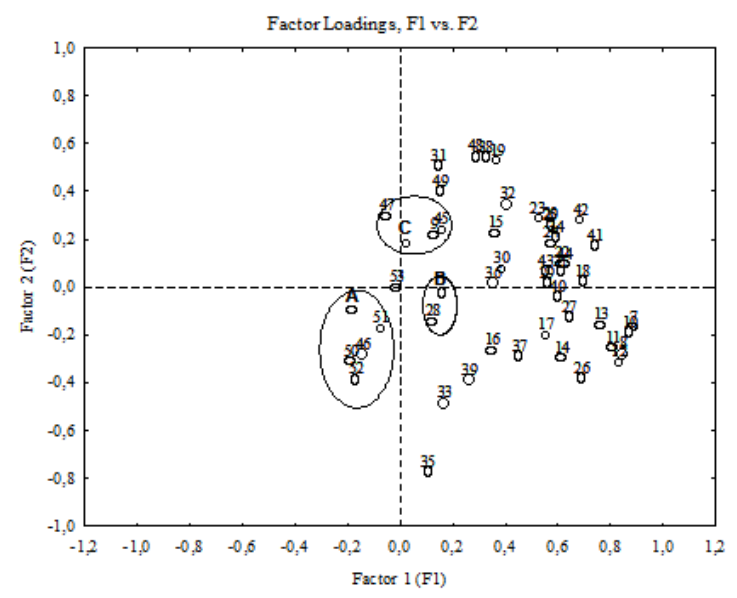

\begin{tabular}{|c|c|c|c|c|c|c|c|}
\hline & iable & F1 & F2 & \multicolumn{2}{|c|}{ Variable } & F1 & F2 \\
\hline 7 & HW & 0.89 & -0.17 & 32 & FaW & 0.41 & 0.34 \\
\hline 8 & $\mathrm{HaW}$ & 0.85 & -0.28 & 33 & EL & 0.17 & -0.49 \\
\hline 9 & HoW & 0.13 & 0.22 & 34 & $A L$ & 0.59 & 0.20 \\
\hline 10 & $\mathrm{MbH}$ & 0.87 & -0.19 & 35 & FarL & 0.11 & -0.78 \\
\hline 11 & $\mathrm{CH}$ & 0.81 & -0.26 & 36 & CaL & 0.36 & 0.01 \\
\hline 12 & $\mathrm{HH}$ & 0.83 & -0.32 & 37 & BaL & 0.46 & -0.29 \\
\hline 13 & HT & 0.77 & -0.16 & 38 & LoL & 0.33 & 0.54 \\
\hline 14 & $\mathrm{HCH}$ & 0.62 & -0.30 & 39 & NP & 0.26 & -0.39 \\
\hline 15 & CW & 0.37 & 0.23 & 40 & TP & 0.60 & -0.05 \\
\hline 16 & $\mathrm{NL}$ & 0.35 & -0.26 & 41 & KP & 0.74 & 0.17 \\
\hline 17 & SL & 0.56 & -0.20 & 42 & $C P$ & 0.69 & 0.28 \\
\hline 18 & BED & 0.69 & 0.02 & 43 & FP & 0.55 & 0.06 \\
\hline 19 & $B D$ & 0.37 & 0.53 & 44 & HP & 0.63 & 0.09 \\
\hline 20 & CW & 0.57 & 0.26 & 45 & EWH & 0.16 & 0.24 \\
\hline 21 & $\mathrm{CL}$ & 0.61 & 0.06 & 46 & $\eta$ & -0.14 & -0.29 \\
\hline 22 & BSL & 0.62 & 0.10 & 47 & a & -0.05 & 0.29 \\
\hline 23 & HSL & 0.52 & 0.28 & 48 & $\beta$ & 0.29 & 0.54 \\
\hline 24 & BuL & 0.58 & 0.18 & 49 & $\varphi$ & 0.16 & 0.40 \\
\hline 25 & LL & 0.57 & 0.26 & 50 & $\varepsilon$ & -0.19 & -0.31 \\
\hline 26 & $B L$ & 0.69 & -0.39 & 51 & $\omega$ & -0.07 & -0.17 \\
\hline 27 & HeL & 0.64 & -0.13 & 52 & $\theta$ & -0.17 & -0.39 \\
\hline 28 & SkL & 0.13 & -0.15 & 53 & $\delta$ & -0.01 & -0.01 \\
\hline 29 & FaL & 0.56 & 0.01 & A & MD & -0.18 & -0.10 \\
\hline 30 & $\mathrm{HeW}$ & 0.39 & 0.08 & B & $C D$ & 0.16 & -0.03 \\
\hline 31 & SkW & 0.15 & 0.50 & C & L & 0.02 & 0.18 \\
\hline & ctors & & igenva & & & tal var & \\
\hline & F1 & & & 65 & & 25,30 & \\
\hline & F2 & & & 28 & & 8,55 & \\
\hline
\end{tabular}

Figure 3

Results of the principal component analysis in Menorca male horses $(n=200)$

The ellipses showed the most closely correlated traits with the three performance aptitude groups. Factor coordinates are shown, where: $F$ corresponds to Factor 1 or 2, respectively.

related to skull length, the Menorca dressage group to most of the hind limb angles (stifle, femur and leg) and the leisure group to the scapula angle, height of withers and withers-hip equilibrium. The results are consistent with the Duncan test analyses carried out (Table 4).

The study by Dolvik \& Klemetsdal (1999) revealed that conformation was responsible for $10 \%-12 \%$ of the variation in racing performance traits, which demonstrated the importance of direct selection in breeding values for this type of performance aptitude. As it is, the different hind limb angular conformation observed between the three performance aptitudes groups studied (Table 4, 5 and Figure 3), could be included in the breeding program of the breed to determine the functional potential of the animals for dressage performance.

\section{Acknowledgements}

This work was funded by the Breeders Association of Menorca Horses (http://www.cavallsmenorca.com) and the research project „Conservación y Gestión sostenible de la raza equina menorquina mediante la caracterización genética y morfológica: Estrategias para el mantenimiento de la diversidad genética« RZ2008-00011-00-00, financed by the National Program of Resources and Agrifood Technologies (the Ministry of Education and Science's national sub-program of genetic resources for agrifood interests).

\section{References}

Abràmoff MD, Magelhaes PJ, Ram SJ (2004) Image Processing with ImageJ. Biophot Int 11, 36-42

Azor PJ, Valera M, Gómez MD, Goyache F, Molina A (2007). Genetic characterization of the Spanish Trotter horse breed using microsatellite markers. Genet Mol Biol 30, 37-42 
Barrey E, Desliens F, Poirel D, Biau S, Lemaire S, Rivero JLL, Langlois B (2002) Early evaluation of dressage ability in different breeds. Equine Vet J 34 (Suppl.), 319-324

Brooks SA, Makvandi-Nejad S, Chu E, Allen JJ, Streeter C, Gu E, McCleery B, Murphy BA, Bellone R, Sutter NB (2010) Morphological variation in the horse: defining complex traits of body size and shape. Anim Genet 41 (Suppl.), 159-65

Cañon J, Checa ML, Carleos C, Vega-Pla JL, Vallejo M, Dunner S (2000) The genetic structure of Spanish Celtic horse breeds inferred from microsatellite data. Anim Genet 31, 39-48

Cervantes I, Baumung R, Molina A, Druml T, Gutiérrez JP, Sölkner J, Valera M (2009) Size and shape analysis of morphofunctional traits in the Spanish Arab horse. Livest Sci 125, 43-49

Dolvik NI, Klemetsdal G (1999) Conformational Traits of Norwegian Cold-blooded Trotters: Heritability and the Relationship with Performance. Acta Agric Scan, Section A - Anim Sci 49, 156-162

Duberstein KJ (2012) Evaluating Horse Conformation. UGA Cooperative Extension Bulletin 1400

García D, Checa ML, García-Atance P, Dunner S, Cañón J (2000) [Proc IX National Meeting of Breeding Genetics, Universidad Autónoma de Barcelona, Barcelona, Spain [in Spanish]

Geladi P, Kowalski BR (1986) Partial least-squares regression: a tutorial. Anal Chim Acta 185, 1-17

Gómez MD, Valera M, Molina A, Gutiérrez JP, Goyache F (2009) Assessment of inbreeding depression for body measurements in Spanish Purebred (Andalusian) horses. Livest Sci 122, 149-155

Gómez MD, Azor PJ, Alonso ME, Jordana J, Valera M (2012) Morphological and genetic characterization of Spanish heavy horse breeds: Implications for their conservation. Livest Sci 144, 57-66

Holmström M, Philipsson J (1993) Relationships between conformation, performance and health in 4-year-old Swedish Warmblood Riding Horses. Livest Prod Sci 33, 293-312

Holmström M, Magnusson LE, Philipsson J (1990) Variation in conformation of Swedish Warmblood horses and conformational characteristics of élite sport horses. Equine Vet J 22, 186-193

Komosa M, Purzyc H (2009) Konik and Hucul horses: A comparative study of exterior measurements. J Anim Sci 87, 2245-2254

Lanari MR, Taddeo H, Domingo E, Centeno MP, Gallo L (2003) Phenotypic differentiation of exterior traits in local Criollo Goat Population in Patagonia (Argentina). Arch Tierz 46, 347-356

Langlois B, Froideveaux J, Lamarche L, Legault C, Legault P, Tassencourt L, Théret M (1978) [Analysis of relationships between morphology and gallop, trot and jumping abilities in horses]. Ann Génét Sél Anim 10, $443-474$ [in French]

Langlois B (1979) French results on the analysis of relationship between morphology and gallop, trot and jumping abilities in horses. In: Proc 30th Ann Meet EAAP, Harrogate, UK

Lawrence LA (2006) Horse Conformation Analysis. Washington State University Extension, 1-8 pp

Marqués J (2001). [El caballo menorquín.] En: Grupo Fer (eds.) Libro de Caballería de las Islas Baleares. Palma de Mallorca, España. [in Spanish]

Mawdsley A, Kelly EP, Smith FH, Brophy PO (1996) Linear assessment of the Thoroughbred horse: an approach to conformation evaluation. Equine Vet J 28, 461-467

Molina A, Valera M, Dos Santos R, Rodero A (1999) Genetic parameters of morphofunctional traits in Andalusian horse. Livest Prod Sci 60, 295-303

Okpeku M, Yakubu A, Peters SO, Ozoje MO, Ikeobi CON, Adebambo OA, Imumorin IG (2011) Application of multivariate principal component analysis to morphological characterization of indigenous goats in Southern Nigeria. Acta Agric Slov 98, 101-109

Pinto LFB, de Almeida FQ, Quirino CR, de Azevedo PCN, Cabral GC, Santos EM, Corassa A (2008) Evaluation of the sexual dimorphism in Mangalarga Marchador horses using discriminant analysis. Livest Sci 119, 161-166

Pretorius SM, van Marle-Köster E, Mostert BE (2004) Description of the Friesian Horse population of South Africa and Namibia. S Afr J Anim Sci 34, 149-157

De Rochambeau H, Fournet-Hanocq F, Vu Tien Khang J (2000). Measuring and managing genetic variability in small populations. Ann Zootech 49, 77-93 
Takaendengan BJ, Noor RR, Adiani S (2011) Morphometric Characterization of Minahasa Horse for Breeding and Conservation Purposes. Media Peternakan 34, 99-104

Vostrý L, Čapková Z, Přibyl J, Mach K (2011) Analysis of Czech cold-blooded horses: genetic parameters, breeding value and the influence of inbreeding depression on linear description of conformation and type characters. Czech J Anim Sci 56, 217-230

Yakubu A, Akinyemi MO (2010) An evaluation of sexual size dimorphism in Uda sheep using multifactorial discriminant analysis. Acta Agric Scana, Section A - Anim Sci 60, 74-78

Zechner P, Zohman F, Sölkner J, Bodo I, Habe F, Marti E, Brem G (2001) Morphological description of the Lipizzan horse population. Livest Prod Sci 69, 163-177 